\title{
Filosofía y cristianismo. Algunas aportaciones desde J. Ratzinger
}

En este número de Pensamiento y Cultura hemos querido ofrecer un pequeño homenaje al pensamiento filosófico de Joseph Ratzinger, en el año en el que ha dejado la cátedra de san Pedro. En él encontramos un ejemplo paradigmático de diálogo en torno a la racionalidad de la fe y la relación de esa racionalidad con la cultura contemporánea.

Para el teólogo bávaro, razón y fe, filosofía y teología, están vinculadas en el origen del cristianismo, así como en su presente y su futuro. Es una idea repetida constantemente por él que la síntesis entre razón y fe -ilustración y cristianismo- es una argumento que se remonta a los mismos orígenes del cristianismo (e incluso antes, en el ámbito del pensamiento judío). De acuerdo con J. Ratzinger, "según esta perspectiva, el cristianismo tiene sus precursores y su preparación interna en la ilustración filosófica, no en las religiones". Esto es, el fundamento de la fe cristiana no es la poesía ni la política, sino el conocimiento. Así, la ilustración misma se convirtió en religión, y no en su antagonista, como por el contrario había sucedido en el ámbito griego, dentro del cual el concepto filosófico de Dios había surgido casi siempre en oposición a las religiones pre-cristianas. Se entiende así que el cristianismo pudiera comprender a sí mismo como vera philosophia, esto es, como un saber universal y destinado a todos, llamado a debatirse en pie de igualdad con las concepciones filosóficas.

Por otro lado, esa decisión inicial del cristianismo de comprenderse a sí mismo más como una filosofía que como una religión, sólo fue posible porque la filosofía tuvo desde el principio un carácter práctico, como forma de vida. Es decir, porque ella está inmersa en el mundo vital. La comprensión de la filosofía en la época germinal del cristianismo se acercaba más a la de una forma de vida que a la del ejercicio académico contemporáneo. Es conocida, en esta misma línea, la tesis de Pierre Hadot en relación con el carácter práctico de la filosofía en la Antigüedad y su calificativo de "ejercicio espiritual".

Este encuentro y fusión entre ilustración y fe tuvo consecuencias tanto para la comprensión del cristianismo como para la concepción 
misma de la filosofía, de las que aún somos herederos. Por una parte, permitió la introducción de nuevas temáticas en el ámbito filosófico: historia y libertad, por mencionar solamente los conceptos más evidentes. Por otra, se hizo perentorio reflexionar sobre los postulados mismos de la filosofía, en particular, sobre la identificación de lo divino con la naturaleza. La consecuencia de este primer encuentro, que Ratzinger considera paradigmático, no fue una reducción o constreñimiento de la razón, sino precisamente su mismo ensanchamiento, tanto temática como metodológicamente.

Los tres artículos que componen esta sección reflexionan sobre algunas particularidades de este encuentro entre fe/religión/creencias y razón/racionalidad. El texto de Euclides Eslava, "Mito, religión y cultura. J. Ratzinger y las religiones", reflexiona sobre el hecho religioso y su relación con el mito, en el marco de lo que podríamos llamar la filosofía de la religión de J. Ratzinger. A partir de allí, se hace una propuesta sobre el diálogo interreligioso y el papel de la religión en el diálogo intercultural. El artículo del J.M. Barrio, "Circularidad fe y razón en Joseph Ratzinger/ Benedicto Xvi”, aborda la relación hermenéutica entre fe y razón a partir de la determinación del contenido intelectual de la fe y su alianza con la filosofía. El texto de C. Soler, "Fe y política en Joseph Ratzinger" estudia un caso concreto de esta relación entre fe y razón. Según el autor, hay en el pensamiento del teólogo alemán aportaciones ineludibles para la renovación de las teorías de la relación entre la religión y el Estado que vale la pena descubrir.

Hemos querido con estos artículos, en sintonía con otros ya publicados en nuestra revista, consolidar el carácter lugar de encuentro interdisciplinar al que está llamado la filosofía misma en nuestro tiempo. El carácter plural del saber mismo invita a buscar ámbitos de diálogo en los que las varias disciplinas salgan mutuamente fortalecidas y enriquecidas, así como nuestra concepción de hombre y de mundo.

Claudia Carbonell

Editora 